DOI: https://doi.org/10.47405/mjssh.v5i11.619

\begin{tabular}{|c|c|}
\hline (7) & Malaysian Journal of Social Sciences and Humanities (MJSSH) \\
\hline Malaysian Journal of & Volume 5, Issue 11 , November 2020 \\
\hline (Mu-ssH) & e-ISSN : 2504-8562 \\
\hline & $\begin{array}{l}\text { Journal home page: } \\
\text { www.msocialsciences.com }\end{array}$ \\
\hline
\end{tabular}

\title{
Pandangan Penduduk Terhadap Program Penempatan Semula Penduduk di Perumahan Awam Seri Melaka, Kuala Lumpur
}

\author{
Nor Azman Shah Abd Rahman', Azima Abdul Manaf1 \\ ${ }^{1}$ Program Sains Pembangunan, Pusat Pengajian Sosial, Pembangunan dan Persekitaran, \\ Fakulti Sains Sosial dan Kemanusiaan, Universiti Kebangsaan Malaysia (UKM)
}

Correspondence: Nama Azima Abdul Manaf (azima@ukm.edu.my)

\begin{abstract}
Abstrak
Pembangunan semula bandar menyumbang kepada kemajuan ekonomi dan sosial negara Namun, pembangunan yang melibatkan penempatan semula penduduk asal telah menyumbang kepada impak negatif. Ini kerana proses penempatan semula menimbulkan pelbagai isu yang menjadi kerisauan penduduk asal sehingga mendorong penduduk bertindak membantah usaha penempatan semula tersebut sehingga mengganggu kelancaran projek pembangunan semula bandar. Kajian ini bertujuan untuk membincangkan tentang pandangan penduduk sebab berlakunya bantahan terhadap cadangan penempatan semula penduduk di Perumahan Awam Seri Melaka, Bandar Tun Razak Kuala Lumpur. Kajian ini telah menemu bual 70 orang responden yang merupakan pemilik rumah di Perumahan Awam Seri Melaka, Kuala Lumpur dan maklum balas yang diperoleh telah dianalisis menggunakan kaedah analisis deskriptif dan korelasi Pearson bagi memenuhi objektif kajian ini. Hasil dapatan kajian melalui analisis deskriptif mendapati terdapat tiga aspek utama sebab berlakunya bantahan terhadap cadangan penempatan semula di kawasan kajian iaitu aspek sosiobudaya, sosioekonomi dan sosiopolitik dan undang-undang. Dalam aspek sosiobudaya, hubungan keakraban yang terjalin antara kejiranan telah menjadi penghalang kepada cadangan penempatan semula kerana penduduk tidak mahu hubungan yang sedia terjalin ini terputus akibat pelaksanaan penempatan semula. Dalam aspek sosioekonomi pula, kegagalan pihak berkuasa menyediakan rumah gantian yang lebih luas dan selesa mendorong kepada keputusan penduduk membantah usaha penempatan semula. Manakala dalam aspek sosiopolitik dan undang-undang mendapati penduduk telah menggunakan hak mereka sebagai pemilik yang sah berlandaskan undang-undang untuk mempertahankan hak mereka selagi mana tuntutan yang dikemukakan kepada pihak berkuasa tidak dipersetujui. Selain itu, hasil dapatan kajian melalui analisis korelasi Pearson mendapati ketiga-tiga aspek utama sebab berlakunya bantahan mempunyai hubungan yang signifikan di antara satu sama lain. Ini memberi gambaran bahawa tiada satu aspek pun yang boleh diabaikan oleh pihak berkuasa dalam menangani masalah bantahan daripada penduduk. Hal ini penting kepada pihak berkuasa dalam merangka pelan pembangunan dan polisi berkaitan penempatan semula penduduk sebelum sesuatu projek pembangunan semula bandar dapat dilaksanakan.
\end{abstract}

Kata kunci: pembangunan semula bandar, pembangunan, penempatan

\section{Population's View on Residence Program at Seri Melaka Public Housing, Kuala Lumpur}

\section{Abstract}


Urban redevelopment may contribute to economic and social development of the country. However, the development which involves the resettlement of peoples contributed to negative impact. This is because the resettlement process caused several issues that become concerns amongst the peoples involved which encourage them to protest and such act may interferes the smooth of development project. This study aimed to discuss the views of residents in public housing Seri Melaka, Bandar Tun Razak, Kuala Lumpur behind their protests against the relocation effort by authority. This study was interviewed 70 respondents those the owner of public housing in Seri Melaka, Kuala Lumpur and all their feedbacks then analyzed using descriptive analysis and Pearson Correlation method in order to meet the objectives of this study. Results of the study via descriptive analysis had found 3 key aspects of resident object to the proposed relocation of the study area, namely the socio-cultural, socioeconomic and socio-political and law aspects. In the socio-cultural aspect, the closeness of the relationship between the neighbourhoods has become an impediment to the proposed relocation because the people do not want the existing ties disconnected as a result of the relocation. In the socioeconomic aspect, the failure of the authority to provide a replacement home more spacious and comfortable lead to the decision of the residents opposing the relocation effort. While in the aspect of political and law found residents were using their right as owners in accordance with the law to defend their rights as long as the claims are failed to fulfil by the authority. In addition, the results of the findings through the Pearson correlation analysis get the three key aspects of residents objection has significant relationships with each other. This gives the impression that no one even aspect that can be ignored by the authority in addressing the problem of opposition from residents. This is important to guide authority in developing development plan and resettlement policies prior to an urban redevelopment projects can be implemented.

Keywords: urban redevelopment, development, resettlement

\section{Pengenalan}

Rancangan Fizikal Negara Ke-3 (RFN-3) menyasarkan jumlah penduduk Malaysia berjumlah 46.1 juta pada tahun 2040 di mana 85 peratus daripadanya dijangka tinggal di dalam kawasan bandar berbanding jumlah penduduk seramai 31.4 juta pada tahun 2015. Tahap urbanisasi yang tinggi ini memerlukan pembangunan semula kawasan bandar sedia ada untuk menampung peningkatan penduduk dan disesuaikan dengan keperluan semasa supaya kawasan bandar kekal berdaya huni. Antara faktor-faktor yang membawa kepada keperluan pembangunan semula adalah kerana peningkatan jumlah bangunan lama semakin usang dan tidak memenuhi piawaian semasa, keperluan penambahan stok hartanah khususnya kediaman bagi menampung peningkatan penduduk dan mewujudkan peluang pekerjaan, sumber tanah yang semakin terhad di bandar-bandar utama, keperluan untuk mengoptimumkan guna tanah dan mengekal dan meningkatkan daya saing bandar. Pembangunan semula merupakan proses perkembangan dan pembangunan kawasan bandar yang memerlukan pengambilan tanah dan kebiasaannya melibatkan perpindahan fizikal penduduk yang telah menetap di atas tanah tersebut. Proses pengambilan balik tanah dan penempatan semula penduduk perlu dilaksanakan untuk menaik taraf kehidupan lebih daripada 1 bilion masyarakat yang hidup dalam kawasan usang di seluruh dunia yang kebanyakannya di negara berpendapatan rendah dan sederhana (Vincent, 2017).

Penduduk yang terlibat dengan proses penempatan semula ke suatu tempat lain sering berdepan dengan pelbagai risiko secara langsung dan tidak langsung. Gaya dan corak kehidupan asal terganggu biarpun pembangunan bandar baru dikatakan membawa kebaikan secara umumnya. Namun demikian, pemindahan sering kali memberi kesan negatif ke atas pengeluaran, mengganggu jaringan sosial, menjadi punca kemiskinan penduduk marginal yang dipinggirkan, memberi kesan negatif terhadap identiti budaya yang sekian lama dipegang oleh penduduk dan meningkatkan tahap risiko epidemik serta masalah kesihatan (Courtland, 2003). Penempatan semula penduduk mempunyai kesan buruk terutamanya kepada sesetengah kumpulan penduduk seperti orang kurang upaya dan orang-orang tua yang sering mempunyai kesukaran tertentu yang menyesuaikan diri di penempatan baharu. Penduduk yang mempunyai keterbatasan mobiliti, seperti golongan Orang Kelainan Upaya (OKU) dan individu 
berpendapatan rendah, mungkin mendapati sukar untuk memenuhi keperluan harian kerana kehilangan kemudahan dan perkhidmatan yang mereka sering bergantung.

Abebe (2013) menyatakan bahawa penempatan semula penduduk cenderung kepada beberapa risiko. Walaupun penempatan semula membolehkan penduduk mendapat tempat tinggal yang lebih baik, namun risiko kehilangan pendapatan, penukaran sekolah untuk anak-anak, masalah kesihatan dan kehilangan simpanan telah dilaporkan menjadi masalah biasa yang dihadapi penduduk yang terlibat. Impak penempatan semula penduduk menimbulkan kesan yang berbagai baik dari segi kehilangan kelebihan lokasi seperti jarak yang biasa ke tempat kerja atau akses kepada kemudahan awam dan perkhidmatan sosial, pertambahan kos perjalanan dan perbelanjaan yang berkaitan dengan perubahan keluarga. Menurut Selvi (2012), masalah penduduk yang rata-rata miskin dan berusia lanjut telah mengalami pelbagai masalah ekonomi dan sosial yang kompleks akibat pemindahan ke lokasi lain secara paksaan ke atas mereka. Dalam pada itu juga, Downing (2002) menambah dua kesan atau risiko pemindahan penduduk secara paksaan adalah mangsa pemindahan menghadapi kesukaran dalam mendapatkan perkhidmatan komuniti dan keganasan terhadap hak kemanusiaan.

Isu yang timbul kesan daripada proses penempatan semula telah membangkitkan bantahan penduduk terdapat cadangan pembangunan semula yang diketengahkan oleh pihak berkuasa.. Ini bermakna penempatan semula hanya boleh dilaksanakan selepas mendapat kebenaran daripada pemiliknya. Wisko (2009) juga menyatakan bahawa penempatan semula penduduk dari penempatan asal telah membangkitkan bantahan penduduk kerana ketidakpuasan hati terhadap isu-su yang berbangkit daripada tindakan penempatan semula. Sebagai contoh, isu pembangunan semula di tapak Perumahan Awam Flat Pekeliling yang telah mencetuskan bantahan beramai-ramai penghuninya (Irwan, 2009). Selain itu, terdapat juga beberapa bantahan lain penduduk di kawasan cadangan semula yang berkaitan dengan cadangan pembangunan semula perumahan awam seperti yang dicadangkan oleh pihak berkuasa seperti di Flat Seri Labuan, Pangsapuri Bukit Keramat dan Setapak Jaya, Kuala Lumpur (Fariz, 2015).

Berdasarkan kepada permasalahan tersebut, pemahaman sebenar penduduk yang terlibat dalam program penempatan semula penduduk perumahan awam telah diteliti bagi memahami sebab kepada bantahan penduduk yang terlibat. Ini kerana walaupun secara umumnya pembangunan semula memberikan banyak manfaat kepada penduduk yang terlibat pada masa hadapan, namun bantahan daripada penduduk telah menimbulkan penangguhan pelaksanaan kerja di tapak yang dirancang oleh pihak agensi.

\section{Kajian Lepas}

Pembangunan semula adalah satu usaha untuk mengubah rupa bentuk fizikal di kawasan bandar (Lafer, 1977). Pembangunan semula yang dijalankan di sesebuah bandar bertujuan untuk mengatasi masalah kemunduran dan kemerosotan daripada terus berlaku sehingga berupaya menjejaskan keharmonian dan kesejahteraan penduduk setempat. Di samping itu, pembangunan semula juga bertujuan untuk meningkatkan tahap sosial penduduk dari segi struktur fizikal pembangunan dan petempatan. Urban Development Authority (UDA) telah mendefinisikan pembangunan semula bandar sebagai satu proses untuk memperbaharui tanah dan bangunan lama di kawasan bandar melalui pembinaan struktur baru di atas tapak bangunan lama demi mencapai pulangan ekonomi yang lebih tinggi. Dalam konteks ini, keadaan sekeliling pula akan diperbaiki dengan penyediaan kemudahan awam yang lengkap dan sempurna (Laporan Tahunan Perbadanan Pembangunan Bandar, 1984).

Oleh yang demikian, konsep pembangunan semula merupakan satu proses pembangunan fizikal yang terancang dalam usaha menghapuskan kawasan perumahan awam yang sesak dan tidak sihat untuk didiami di bandar. Selain itu ia bertujuan untuk mewujudkan pemandangan dan imej kawasan perumahan awam di bandar raya yang lebih baik. Di samping mengubah taraf sosioekonomi penduduk setempat ke satu tahap yang lebih baik, mewujudkan kawasan kejiranan yang selesa dan selamat serta meningkatkan nilai hartanah kawasan yang dahulunya usang kepada kawasan yang bernilai tinggi pada masa hadapan. 
Bantahan atau penentangan terhadap idea penempatan semula penduduk adalah perkara yang biasa dan dikategorikan sebagai normal dan boleh dijangka (Anthony, 1991). Penentangan ini boleh berlaku atas beberapa sebab seperti wujudnya pertimbangan dalam konteks material atau mungkin juga disebabkan oleh sikap manusia itu sendiri yang sukar menerima perubahan. Dalam suatu peringkat asas, semua bentuk perubahan walaupun perubahan tersebut adalah positif, namun berurusan dengan manusia itu sendiri boleh menjadi sukar terutamanya apabila melibatkan proses rundingan dan peralihan daripada lama kepada yang baru (Marris, 1975).

Penduduk yang terlibat dengan projek pembangunan semula mempunyai pengaruh yang besar ke atas projek berkenaan sekiranya permintaan mereka tidak dipenuhi dan penduduk akan bertindak dalam pelbagai cara untuk menentang atau membantah selagi mana suara mereka tidak didengar (Hanna et al., 2016). Oleh itu, penyertaan aktif penduduk yang terlibat dalam proses penempatan semula adalah penting jika terdapat sebarang kemungkinan berkait dengan isu pengurusan risiko dan perubahan mata pencarian. Terdapat bukti yang menunjukkan bahawa semakin ramai penduduk terlibat dalam keputusan berhubung dengan bagaimana, di mana dan bila mereka berpindah, semakin besar kemungkinan mereka cepat dapat menyesuaikan diri dengan keadaan suasana yang baharu serta dapat meminimumkan rasa tekanan terhadap penempatan semula (Reddy et al., 2015). Pelaksana projek penempatan semula perlu memperjelaskan keseluruhan proses penempatan semula dengan mendekati golongan yang terjejas melalui proses perundingan. Rundingan tersebut perlu dilakukan dengan cara yang adil dan jujur, ada keterbukaan, saling menghormati dengan niat untuk menyampaikan maklumat untuk manfaat bersama (Reddy et al., 2015). Proses penglibatan ini perlu peka terhadap konteks budaya tempatan dan disokong oleh analisis gender untuk memastikan wanita dapat mengambil bahagian dan dapat dipengaruhi dengan penempatan semula serta menyumbang kepada proses membuat keputusan (Eftimie et al., 2009).

Vanclay (2017) pula menyentuh mengenai proses penempatan semula yang lebih cenderung dalam memfokuskan hampir semata-mata mengenai isu yang berkaitan dengan memindahkan isi rumah yang terjejas oleh projek pembangunan. Namun terdapat kekurangan pertimbangan yang diberikan kepada aspek kebimbangan komuniti asal yang boleh dipengaruhi oleh projek pembangunan atau penempatan semula. Ketibaan kumpulan penduduk yang ditempatkan semula meningkatkan permintaan barangan dan perkhidmatan. Walaupun hal ini meningkatkan sektor perusahaan kecil sebagai perkembangan yang positif, namun ia juga menyumbang kepada peningkatan permintaan terhadap perkhidmatan awam yang mungkin tidak dapat menampung permintaan tambahan. Mungkin terdapat juga peningkatan kesesakan atau penangguhan dalam mengakses perkhidmatan seperti keperluan utama air, elektrik, bahan api dan juga makanan. Pertambahan permintaan dalam ekonomi tidak dapat dielakkan membawa kepada inflasi tempatan. Oleh itu, kesejahteraan komuniti asal secara tidak langsung terjejas oleh kedatangan penduduk yang dipindahkan ke kawasan mereka.

Sharifah (2012) pula menyatakan bahawa organisasi yang menjalankan program pembangunan semula bandar mesti mendapatkan kerjasama daripada orang ramai. Jika kerjasama ini tidak dimeterai, organisasi tersebut akan gagal untuk mencapai objektif program dan semua pihak akan menanggung akibatnya. Secara amnya, perancangan ini tidak boleh dikuatkuasakan jika komuniti menolaknya. Malahan dalam sistem pentadbiran yang autokratik seperti di Singapura, contohnya sebelum menghantar jentera tolak ke kawasan terlibat, mereka perlu terlebih dahulu menunjukkan yang kerajaan memahami dan menghargai kehendak komuniti. Di Kampung Bharu, pihak perancang bandar gagal dalam mengajukan soalan yang betul kepada penduduk dan juga langsung tidak memikirkan bahana cadangan yang mereka kemukakan. Dalam hal ini, penawaran untuk memindahkan penghuni ke lokasi baru yang jauh dari kawasan asal adalah tindakan yang tidak sensitif dan ditolak oleh penduduk. Ahmed (2005) menegaskan bahawa banyak keputusan penting yang dibuat oleh kerajaan dan komuniti di Maldives yang melibatkan penempatan semula penduduk kerana risiko peningkatan paras air laut hakisan pantai akibat pemanasan global diambil tanpa mengadakan kajian mendalam tentang kesan masa depan terhadap penduduk yang terlibat. Penempatan semula boleh menjadi kaedah yang efektif dalam meningkatkan kualiti perkhidmatan sosial penduduk sekiranya beberapa kelemahan diberikan perhatian iaitu mengekalkan mata pencarian penduduk dan mempercepatkan tempoh penempatan semula. Oleh itu, adalah penting untuk semua bentuk pembangunan di masa hadapan untuk mempunyai strategi dan dasar-dasar pembangunan sosial berdasarkan strategi yang jelas terutama yang 
berkaitan dengan penempatan semula penduduk. Dalam konteks unik di Maldives, penempatan semula penduduk berdasarkan realiti paras air laut yang meningkat dan perubahan iklim boleh memperbaiki tahap sosio-ekonomi penduduk ke tahap yang lebih baik apabila berpindah ke kawasan yang baru.

Bagi meneruskan usaha pembangunan demi kemajuan ekonomi negara, pemindahan secara sukarela atau paksaan perlu dilakukan oleh pihak yang berkuasa. Dalam hal ini, M. Cernea (1999) telah membangunkan satu model yang dipanggil Development Induced Displacement and Resettlement $(D I D R)$ yang menggariskan lapan faktor risiko yang dikenalpasti saling berkaitan untuk mengatasi sebarang isu berkaitan penempatan semula. Faktor-faktor tersebut adalah kekurangan tanah (Landlessness), kekurangan pekerjaan (Joblessness), kekurangan akses kepada harta awam dan perkhidmatan (loss of access to common property and services), peminggiran ekonomi (marginalisation), perpecahan hubungan sosial (sosial disintegration), tiada tempat berlindung (homelessness), peningkatan penyakit dan kematian (increased morbidity and mortality) dan tiada jaminan makanan (food insecurity). Faktor-faktor ini boleh dikategorikan kepada aspek yang berorientasikan kepada sosio-budaya dan sosio-ekonomi. Di samping itu, model DIDR digunakan untuk tujuan perancangan serta menilai kesan penempatan semula.

Frank (2016) dalam kajiannya mengenai keperluan penempatan semula penduduk akibat daripada pelaksanaan projek pembangunan untuk kemajuan ekonomi negara telah mengguna pakai model DIDR. DIDR merupakan konsep asas untuk mengadakan proses rundingan bersama penduduk yang terlibat dengan pemindahan supaya risiko bantahan dapat dielakkan walaupun tidak sepenuhnya. Dengan mengguna pakai model DIDR, pihak berkuasa juga dapat mengambil peluang daripada proses penempatan semula untuk meningkatkan taraf hidup penduduk selain dapat mengurangkan kesan emosi dalam kalangan penduduk serta meminimumkan impak sosial yang lain. Beliau telah membuat beberapa penambahan terhadap model DIDR yang sedia ada iaitu peningkatan densiti di penempatan baharu, kadar bayaran ganti rugi atau pampasan kepada pemilik dan bukan pemilik, proses rundingan dan keperluan komuniti asal di penempatan baru. Manakala Ahmed (2005), telah menggunakan model DIDR ini dalam kajiannya bagi mendalami risiko pemindahan penduduk dari satu kepulauan kecil di Maldives ke suatu penempatan baru yang tiada lagi sebarang petempatan manusia. Penduduk di kepulauan kecil tersebut perlu dipindahkan oleh pihak kerajaan berikutan pulau di penempatan asal mereka tidak lagi selamat untuk diduduki akibat daripada kesan pemanasan global yang menyebabkan kenaikan paras air laut, kehadiran ombak besar, hakisan pantai dan kemusnahan hidupan coral kerana kenaikan suhu laut. Memandangkan model DIDR tidak pernah diguna pakai ke atas penempatan semula akibat pemanasan global serta pemindahan ke suatu pulau yang tiada lagi penempatan manusia, maka pengkaji telah melakukan beberapa modifikasi ke atas model DIDR. Beliau telah menambah tiga lagi faktor risiko penempatan semula penduduk supaya sesuai dengan konteks kajian di Maldives iaitu adaptasi penduduk ke atas peningkatan paras air laut, kesan perubahan iklim dan bencana alam; akses kepada perkhidmatan hospital dan pendidikan; dan akses kepada infrastruktur fizikal.

Prabhat (2013) pula telah menggunakan model DIDR bagi mengkaji risiko pembangunan penduduk yang terlibat dengan pemindahan akibat kepesatan pembangunan industri di India. Beliau telah mengenal pasti punca penentangan dan ketidakpuasan hati penduduk yang terlibat dengan pemindahan ke kawasan yang baru serta kesan negatif yang perlu ditangani oleh pihak berkuasa supaya kebajikan penduduk berkenaan terjaga. Impak yang ketara akibat pengabaian pihak berkuasa terhadap keperluan penduduk yang dipindahkan adalah peningkatan kadar kemiskinan di India, peningkatan buruh kanakkanak dan wanita, kenaikan kadar keganasan domestik serta kekurangan bekalan makanan. Selain itu, Andrea (2011) telah mengkaji kerangka yang sesuai diguna pakai sebagai panduan pemindahan penduduk akibat daripada perubahan iklim yang menyebabkan bencana alam seperti banjir, gempa bumi dan puting beliung. Beliau telah mengintegrasikan pendekatan DIDR dengan Climate Change Displacement and Resettlement (CCDR). Beliau mendapati bahawa kebanyakan sarjana yang menjalankan kajian menggunakan DIDR hanya fokus kepada kaedah pengurusan bagi menghadapi situasi yang tertentu dan mengurangkan risiko kegagalan pelaksanaan pemindahan manusia. Manakala CCDR adalah satu medium bantuan berjangka masa pendek melainkan situasi yang dihadapi adalah kompleks. Kombinasi kedua-dua model ini akan memudahkan pelaksanaan pemindahan penduduk tanpa sukarela serta dapat menguruskan situasi atau masalah yang dihadapi dengan baik akibat daripada perubahan iklim yang sangat kompleks. 
Sejal (2015) dalam kajiannya mengenai kesan terhadap pelbagai projek pembangunan di Ahmedabad yang melibatkan pemindahan atau penempatan semula penduduk di bandar tersebut secara besarbesaran telah menyebabkan penduduk yang miskin terus bertambah miskin apabila ditempatkan semula di satu kawasan yang baharu. Berdasarkan kepada analisis yang menggunakan model DIDR, penduduk miskin di bandar yang dipindahkan ke tempat baharu akibat daripada pembangunan telah menjadikan penduduk tersebut semakin tertekan atau miskin di tempat yang baharu. Hal ini kerana pihak berkuasa telah mengabaikan semua risiko atau garis panduan tentang pemindahan semula penduduk serta polisi yang lemah semasa pelaksanaan sesuatu pembangunan.

Rumusannya, model DIDR telah diguna pakai untuk mengkaji risiko atau impak terhadap penduduk akibat daripada kepesatan pembangunan. Kajian yang menggunakan DIDR ini kebiasaannya digunakan ke atas cadangan pembangunan yang melibatkan pemindahan atau penempatan semula penduduk ke suatu penempatan yang baharu sama ada melintasi sempadan negeri atau daerah juga di kawasan pedalaman atau bandar. Manakala lokasi penempatan semula pula boleh dirujuk ke suatu penempatan yang telah berpenghuni atau suatu kawasan yang kosong yang pernah diduduki oleh sesiapa sahaja di kawasan tersebut. Dalam hal ini, DIDR juga diguna pakai untuk memastikan sesuatu pembangunan dapat dilaksanakan dengan lancar serta meminimumkan sebarang halangan atau risiko penentangan daripada penduduk setempat selain daripada menjaga kebajikan mereka yang dipindahkan ke tempat lain.

\section{Metod Kajian}

Dalam menentukan sebab bantahan penduduk terhadap cadangan pembangunan semula yang akan memindahkan mereka ke satu kawasan perumahan yang baharu, pelbagai kaedah yang sistematik akan digunakan. Kaedah mendapatkan data dan menganalisis data yang diperoleh adalah dari hasil kerja lapangan. Perumahan Awam Seri Melaka, Bandar Tun Razak dipilih sebagai kawasan pilihan kajian kerana Perumahan Awam ini terlibat dengan cadangan pihak kerajaan untuk dibangunkan semula bagi sebagai kawasan yang moden dan maju. Pembangunan semula tersebut akan melibatkan pemindahan penduduk Perumahan Awam Seri Melaka ke satu kawasan yang dicadangkan oleh pihak pemaju selepas cadangan penyusunan pembangunan di sekitar kawasan perumahan awam tersebut dipersetujui oleh pihak kerajaan. Secara umumnya, kerajaan telah bersetuju untuk membangunkan kawasan Perumahan Awam Seri Melaka pada tahun 2011 melalui kaedah penswastaan (Kementerian Wilayah Persekutuan, 2018). Terdapat 201 keluarga yang menduduki Perumahan Awam Seri Melaka yang mana 70 daripadanya adalah pemilik sah unit rumah di perumahan awam tersebut. Manakala 140 keluarga adalah berstatus penyewa unit rumah yang dimiliki oleh pihak Dewan Bandaraya Kuala Lumpur (DBKL 2018).

Borang soal selidik telah diedarkan kepada penduduk yang berstatus pemilik dengan bantuan Persatuan Penduduk Perumahan Awam Seri Melaka. Borang soal selidik diedarkan kepada semua pemilik di Perumahan Awam Seri Melaka yang berjumlah 70 orang (ketua isi rumah). Borang soal selidik ini mengandungi 2 bahagian seperti dalam Jadual 1.

Jadual 1: Reka Bentuk Soal Selidik

\begin{tabular}{lll}
\hline Bahagian A & Profil Responden \\
\hline & \multicolumn{2}{c}{ Risiko Bantahan Penduduk } \\
Bahagian B & i. & Aspek Sosio Budaya \\
& ii. & Aspek Sosio Ekonomi \\
& iii. & Aspek Sosio Politik dan Undang-undang \\
\hline
\end{tabular}

Jadual 1 menunjukkan reka bentuk soal selidik yang dijalankan semasa di kerja lapangan. Bahagian A mempersoalkan responden mengenai faktor profil responden seperti umur, jantina, taraf perkahwinan, tempoh pemilikan rumah, bilangan isi rumah, tahap pendidikan, pekerjaan dan tempoh menetap. Manakala bahagian B pula merupakan faktor risiko bantahan penduduk terhadap cadangan 
pembangunan semula perumahan mereka yang akan menyebabkan mereka perlu berpindah ke satu kawasan penempatan yang baharu. Dalam konteks ini, setiap kenyataan responden diukur berdasarkan 5 skala likert iaitu 1 merujuk kepada sangat tidak bersetuju, skala 2 tidak setuju, skala 3 tidak pasti, skala 4 merujuk kepada setuju dan skala 5 merujuk kepada sangat setuju kepada setiap kenyataan yang diberi.

\section{Analisis dan Perbincangan}

Analisis terhadap sebab-sebab bantahan penduduk telah dibahagikan kepada aspek sosiobudaya, sosioekonomi dan sosio politik dan undang-undang.

\section{Pandangan pendudukterhadap sosiobudaya}

Bagi sosio budaya penduduk dijelaskan melalui semangat solidariti penduduk dalam aspek pertalian silaturahim, kesatuan dan hubungan kejiranan serta aspek identiti dan tradisi seperti cara hidup, adat istiadat, ukhuwah dan kemesraan hubungan dalam masyarakat yang boleh mempengaruhi keputusan penduduk terhadap projek pembangunan yang ingin dilaksanakan. Sehubungan itu, berdasarkan Jadual 2 , majoriti responden bersetuju bahawa hubungan silaturahim antara penduduk akan terjejas selepas berpindah ke perumahan yang baharu iaitu sebanyak 54 peratus dan 13 peratus sangat setuju, 24 peratus tidak pasti dan selebihnya 4 peratus tidak setuju akan hal tersebut. Di samping itu, majoriti responden sangat bersetuju untuk bersatu dan berdiri teguh dalam membuat sebarang tuntutan terhadap pihak berkuasa iaitu 54 peratus daripada responden, 36 peratus bersetuju, 9 peratus tidak pasti dan 1 peratus tidak setuju. Hal ini berikutan mereka sangat bersetuju dan berasa hubungan kejiranan yang terjalin di antara penduduk sekarang sangat baik dan harus dikekalkan iaitu 62 peratus dan 31 peratus bersetuju dan mungkin ia akan berubah bila mereka dipindahkan ke sebuah perumahan awam yang baru. Hal ini disokong daripada profil pemilik yang majoriti daripada mereka telah menetap lebih daripada 20 tahun dan sememangnya semangat kejiranan yang wujud pada masa ini amatlah rapat. Berdasarkan pemerhatian pengkaji, kebanyakan penduduk telah mengenali hampir kesemua penduduk di Perumahan Awam Seri Melaka.

Tambahan pula, majoriti pemilik unit juga bersetuju bahawa tradisi kejiranan yang diamal sekarang akan hilang selepas semua penduduk berpindah ke penempatan baharu iaitu sebanyak 38 peratus, tidak pasti seramai 47 peratus dan yang tidak bersetuju seramai 6 peratus. Dalam aspek kemesraan yang terjalin sekarang sukar diperoleh semula selepas berpindah, majoriti pemilik unit bersetuju dengan hal tersebut iaitu sebanyak 46 peratus, sangat setuju sebanyak 15 peratus, tidak pasti sebanyak 34 peratus dan tidak setuju sebanyak 4 peratus. Oleh itu, dapat dirumuskan bahawa penduduk merasakan diri mereka akan menerima impak negatif daripada proses penempatan semula dan pembangunan semula kawasan perumahan awam dan mereka mengharapkan supaya pihak berkuasa mengadakan langkah yang proaktif supaya kesan negatif berkaitan dengan sosio budaya penduduk dapat dimaksimumkan seperti menempatkan penduduk berhampiran dengan jiran-jiran yang mereka kenali sekarang.

Jadual 2: Pandangan penduduk dalam aspek sosiobudaya

\begin{tabular}{|c|c|c|c|c|c|c|c|}
\hline \multirow{2}{*}{ Bil } & \multirow{2}{*}{ Kenyataan } & \multicolumn{5}{|c|}{ Skala } & \multirow{2}{*}{ Jumlah } \\
\hline & & 1 & 2 & 3 & 4 & 5 & \\
\hline \multicolumn{8}{|c|}{ I Solidariti Penduduk } \\
\hline 1 & $\begin{array}{l}\text { Hubungan silaturahim antara penduduk akan terjejas } \\
\text { selepas berpindah ke perumahan yang baharu }\end{array}$ & 3 & 1 & 29 & 54 & 13 & 100 \\
\hline 2 & $\begin{array}{l}\text { Penduduk boleh bersatu dan berdiri teguh dalam } \\
\text { membuat sebarang tuntutan terhadap pihak berkuasa }\end{array}$ & 0 & 1 & 9 & 36 & 54 & 100 \\
\hline 3 & $\begin{array}{l}\text { Hubungan kejiranan yang terjalin di antara penduduk } \\
\text { sekarang sangat baik dan harus dikekalkan }\end{array}$ & 0 & 1 & 6 & 31 & 62 & 100 \\
\hline \multicolumn{8}{|c|}{ II Identiti dan Tradisi Masyarakat } \\
\hline 1 & Tradisi kejiranan yang diamalkan sekarang akan hilang & 3 & 6 & 47 & 38 & 6 & 100 \\
\hline
\end{tabular}


selepas semua penduduk berpindah ke penempatan

baharu

2

Cara hidup penduduk akan berubah sama sekali semasa

di penempatan yang baharu.

3 Kemesraan yang terjalin sekarang sukar diperoleh

semula selepas berpindah

Jadual 3 menerangkan tentang pandangan responden mengenai hubungan kejiranan yang terjalin di antara penduduk sekarang sangat baik dan harus dikekalkan pada masa ini mendapat nilai min tertinggi dan paling dominan iaitu $M=4.5286, S D=0.6750$ diikuti oleh penduduk boleh bersatu dan berdiri teguh dalam membuat sebarang tuntutan terhadap pihak berkuasa iaitu $M=4.4286, S D=0.7137$. Hal ini menunjukkan bahawa sebab-sebab yang sangat mempengaruhi keputusan responden dalam aspek sosiobudaya berdasarkan nilai purata min melebihi $4.000(M>4.000)$. Berdasarkan pemerhatian pengkaji, pihak berkuasa tidak mempunyai sebarang polisi atau perancangan yang spesifik tentang aspek kejiranan ini yang menyebabkan penduduk sepakat untuk menyukarkan urusan penempatan semula oleh pihak berkuasa. Manakala nilai min yang terendah adalah dari impak proses penempatan semula iaitu tradisi kejiranan yang diamalkan sekarang akan hilang selepas semua penduduk berpindah ke penempatan baharu iaitu $M=3.3857, S D=0.8039$. Manakala yang selebihnya ialah hubungan silaturahim antara penduduk akan terjejas $M=3.7286, S D=0.8151$, kemesraan yang terjalin sekarang sukar diperoleh semula selepas berpindah $M=3.6714, S D=0.8292$ dan cara hidup penduduk akan berubah sama sekali semasa di penempatan yang baharu $M=3.4000, S D=1.0129$. Berdasarkan perangkaan ini, penempatan semula memberikan impak negatif terhadap hubungan silaturahim yang terjalin pada masa ini dan perkara tersebut menjadi faktor yang perlu dititikberatkan oleh pihak berkuasa dalam menggubal polisi penempatan semula penduduk supaya tindakan bantahan penduduk dapat dielakkan.

Jadual 3: Pandangan Penduduk dalam Aspek Sosiobudaya

\begin{tabular}{ll}
\hline Pandangan Penduduk dalam Aspek Sosiobudaya & Min \\
\hline $\begin{array}{l}\text { Hubungan silaturahim antara penduduk akan } \\
\text { terjejas selepas berpindah ke perumahan yang } \\
\text { baharu }\end{array}$ & 3.7286 \\
$\begin{array}{l}\text { Penduduk boleh bersatu dan berdiri teguh dalam } \\
\text { membuat sebarang tuntutan terhadap pihak } \\
\text { berkuasa }\end{array}$ & 4.4286 \\
$\begin{array}{l}\text { Hubungan kejiranan yang terjalin di antara } \\
\text { penduduk sekarang sangat baik dan harus } \\
\text { dikekalkan }\end{array}$ & 4.52857 \\
$\begin{array}{l}\text { Tradisi kejiranan yang diamal sekarang akan } \\
\text { hilang selepas semua penduduk berpindah ke } \\
\text { penempatan baharu }\end{array}$ & \\
$\begin{array}{l}\text { Cara hidup penduduk akan berubah sama sekali } \\
\text { semasa di penempatan yang baharu. }\end{array}$ & 3.3857 \\
$\begin{array}{l}\text { Kemesraan yang terjalin sekarang sukar diperoleh } \\
\text { semula selepas berpindah }\end{array}$ & 3.4000 \\
\hline
\end{tabular}

\section{Pandangan Pendudukdalam aspekSosioekonomi}

Bahagian ini mengukur tentang pandangan penduduk dalam konteks keperluan atau persepsi penduduk bagi aspek sosioekonomi. Sehubungan itu, berdasarkan Jadual 4 dalam konteks rumah gantian yang bakal diperoleh, majoriti responden sangat bersetuju bahawa mereka akan mendapat rumah baharu yang lebih luas dan selesa iaitu 60 peratus, 33 peratus bersetuju dan selebihnya 7 peratus daripada jumlah responden tidak pasti akan hal demikian. Walau bagaimanapun, rata-rata pemilik unit bersetuju dan sangat bersetuju bahawa mereka perlu membayar sejumlah wang untuk mendapatkan rumah gantian yang baharu (48\%) dan nilai pasaran rumah baharu lebih tinggi berbanding rumah yang lama (87\%). Manakala selebihnya iaitu responden yang sangat tidak setuju dan beranggapan mereka tidak 
perlu membayar sejumlah wang untuk mendapatkan rumah gantian yang baharu ialah sebanyak 32 peratus daripada jumlah responden dan sejumlah 20 peratus lagi tidak pasti berkenaan hal demikian. Berdasarkan perangkaan ini, dapat dirumuskan bahawa majoriti responden tidak bersetuju dengan penempatan semula sekiranya mereka tidak mendapat rumah gantian yang lebih luas dan selesa serta mempunyai nilai pasaran yang lebih tinggi daripada rumah asal. Selain itu, majoriti responden akan membantah penempatan semula sekiranya rumah gantian yang diterima kelak dikenakan bayaran atau kos kepada penduduk. Berdasarkan pemerhatian pengkaji, tiada bayaran yang dikenakan kepada penduduk untuk mendapatkan rumah gantian dan rumah gantian tersebut juga dibina lebih luas dan selesa daripada rumah yang asal, namun hampir separuh daripada responden tidak tahu perihal rumah gantian tersebut. Statistik ini jelas menunjukkan bahawa salah satu sebab penduduk membantah adalah kerana ketidaksampaian maklumat atau tidak memahami mengenai perihal penggantian rumah baharu yang menyebabkan mereka berprasangka bahawa terdapat komitmen yang mereka terpaksa tanggung jika menerima rumah gantian.

Dalam konteks peluang ekonomi selepas pembangunan semula, rata-rata responden bersetuju bahawa banyak peluang ekonomi yang tersedia untuk direbut oleh penduduk seperti berniaga kecil-kecilan iaitu sangat setuju (42\%), setuju (38\%), tidak pasti (17\%) dan selebihnya (4\%) tidak bersetuju terhadap peluang pekerjaan yang tersedia. Namun terdapat 10 peratus daripada jumlah responden tidak bersetuju dengan hal demikian. Selain itu, rata-rata pemilik unit iaitu 67 peratus dan 16 peratus setuju dan sangat setuju bahawa kos sara hidup mereka juga akan meningkat selepas pembangunan semula siap dilaksanakan. Berdasarkan perangkaan tersebut, penduduk merasa bimbang selepas mereka berpindah ke perumahan baharu, kos sara hidup mereka akan meningkat antaranya yuran penyenggaraan bangunan bertingkat yang dijangka lebih tinggi berbanding sekarang. Hal ini sedikit sebanyak telah mempengaruhi keputusan penduduk membantah program penempatan semula walaupun majoriti responden bersetuju bahawa banyak peluang ekonomi tersedia apabila pembangunan semula dilaksanakan.

Selain itu, dari segi akses kepada peluang pekerjaan, 62 peratus pemilik unit bersetuju bahawa pekerjaan semasa mereka tidak terjejas jika berpindah ke perumahan yang baharu, manakala 17 peratus tidak pasti dan 1 peratus daripada responden merasakan pekerjaannya akan terjejas. Berdasarkan pemerhatian pengkaji, kebanyakan penduduk bekerja di luar kawasan perumahan mereka sekarang yang mana tidak relevan untuk menukar pekerjaan lain. Namun terdapat juga bilangan yang sangat kecil responden yang bekerja di dalam kawasan Perumahan Seri Melaka seperti pembantu kedai runcit atau kedai makan dan sebagainya terpaksa untuk mencari pekerjaan di tempat lain kerana tapak perniagaan tersebut akan dirobohkan untuk pembangunan semula. Faktor pekerjaan penduduk sekarang tidak terjejas secara signifikan akibat daripada program penempatan semula.

Dari segi akses kepada kemudahan awam, majoriti daripada responden bersetuju (60\%) dan sangat bersetuju (31\%) bahawa jarak untuk menggunakan perkhidmatan pengangkutan awam seperti LRT, ERL dan lain-lain lebih dekat berbanding sekarang dan rata-rata responden merasakan mereka akan mendapat perkhidmatan kesihatan dan pendidikan yang lebih baik selepas penempatan semula. Ratarata penduduk juga sudah selesa dengan tahap kemudahan awam yang ada sekarang dan tidak perlu di naik taraf iaitu sebanyak 39 peratus menyatakan bersetuju, 8 peratus tidak pasti manakala 24 peratus lagi merasakan kemudahan awam semasa perlu dinaiktarafkan. Berdasarkan statistik ini, majoriti penduduk amat mementingkan penyediaan dan pembinaan kemudahan awam yang lebih baik serta berkualiti daripada apa yang mereka nikmati pada hari ini. Sekiranya kemudahan awam seperti pusat kesihatan, sekolah, taska termasuklah pengangkutan awam tidak dirancang untuk dinaiktarafkan oleh pihak berkuasa, maka penduduk pasti membantah keputusan pihak berkuasa untuk melaksanakan penempatan semula. Hal ini selaras dengan dapatan analisis kemudahan asas yang mana majoriti besar responden sangat bersetuju (51\%) dan bersetuju (41\%) bahawa mereka akan menikmati kemudahan dan fasiliti yang lebih baik di perumahan yang baharu. 
Jadual 4: Pandangan penduduk dalam Aspek Sosioekonomi

\begin{tabular}{|c|c|c|c|c|c|c|c|}
\hline \multirow{2}{*}{ Bil } & \multirow{2}{*}{ Kenyataan } & \multicolumn{5}{|c|}{ Skala } & \multirow{2}{*}{ Jumlah } \\
\hline & & 1 & 2 & 3 & 4 & 5 & \\
\hline I & Rumah Gantian & & & & & & \\
\hline 1 & $\begin{array}{l}\text { Penduduk akan mendapat rumah baharu yang } \\
\text { lebih luas dan selesa }\end{array}$ & 0 & 0 & 7 & 33 & 60 & 100 \\
\hline 2 & $\begin{array}{l}\text { Nilainya pasaran rumah baharu lebih tinggi } \\
\text { berbanding rumah yang lama }\end{array}$ & 7 & 0 & 6 & 43 & 44 & 100 \\
\hline 3 & $\begin{array}{l}\text { Penduduk perlu membayar sejumlah wang untuk } \\
\text { mendapatkan rumah gantian yang baharu }\end{array}$ & 18 & 14 & 20 & 39 & 9 & 100 \\
\hline II & $\begin{array}{l}\text { Peluang Ekonomi Selepas Pembangunan } \\
\text { Semula }\end{array}$ & & & & & & \\
\hline 1 & $\begin{array}{l}\text { Banyak peluang ekonomi yang tersedia untuk } \\
\text { direbut oleh penduduk seperti berniaga kecil- } \\
\text { kecilan }\end{array}$ & 1 & 3 & 17 & 38 & 42 & 100 \\
\hline 2 & $\begin{array}{l}\text { Kos sara hidup meningkat selepas pembangunan } \\
\text { semula siap dilaksanakan }\end{array}$ & 4 & 1 & 12 & 67 & 16 & 100 \\
\hline 3 & $\begin{array}{l}\text { Perniagaan kecil-kecilan yang ada di sekitar } \\
\text { perumahan awam pada masa ini tidak akan } \\
\text { diteruskan lagi }\end{array}$ & 4 & 19 & 31 & 43 & 3 & 100 \\
\hline III & Akses kepada Pekerjaan & & & & & & \\
\hline 1 & $\begin{array}{l}\text { Pekerjaan semasa saya tidak terjejas jika } \\
\text { berpindah ke perumahan yang baharu }\end{array}$ & 0 & 1 & 17 & 62 & 20 & 100 \\
\hline 2 & $\begin{array}{l}\text { Banyak peluang pekerjaan tersedia kepada } \\
\text { penduduk setempat }\end{array}$ & 0 & 6 & 11 & 54 & 29 & 100 \\
\hline 3 & $\begin{array}{l}\text { Sebahagian penduduk perlu mencari pekerjaan } \\
\text { lain kerana lokasi perumahan yang baharu jauh } \\
\text { daripada tempat kerja yang lama }\end{array}$ & 4 & 17 & 31 & 37 & 11 & 100 \\
\hline IV & Akses kepada Kemudahan Awam & & & & & & \\
\hline 1 & $\begin{array}{l}\text { Jarak untuk menggunakan perkhidmatan } \\
\text { pengangkutan awam seperti LRT/ERL dan lain- } \\
\text { lain lebih dekat berbanding sekarang }\end{array}$ & 1 & 1 & 7 & 60 & 31 & 100 \\
\hline 2 & $\begin{array}{l}\text { Penduduk akan mendapat perkhidmatan } \\
\text { kesihatan dan pendidikan yang lebih baik } \\
\text { selepas pembangunan semula. }\end{array}$ & 0 & 1 & 7 & 49 & 43 & 100 \\
\hline 3 & $\begin{array}{l}\text { Penduduk sudah selesa dengan tahap } \\
\text { kemudahan awam yang ada sekarang dan tidak } \\
\text { perlu di naik taraf lagi }\end{array}$ & 0 & 24 & 8 & 39 & 29 & 100 \\
\hline $\mathbf{V}$ & Akses kepada Kemudahan Asas & & & & & & \\
\hline 1 & $\begin{array}{l}\text { Penduduk akan menikmati kemudahan dan } \\
\text { fasiliti yang lebih baik di perumahan yang } \\
\text { baharu }\end{array}$ & 1 & 0 & 7 & 41 & 51 & 100 \\
\hline 2 & $\begin{array}{l}\text { Kualiti bekalan air, elektrik dan komunikasi } \\
\text { akan lebih baik di perumahan yang baharu }\end{array}$ & 0 & 1 & 4 & 39 & 56 & 100 \\
\hline 3 & $\begin{array}{l}\text { Keselamatan atau masalah vandalisme lebih } \\
\text { terkawal selepas penduduk berpindah ke } \\
\text { perumahan yang baharu }\end{array}$ & 1 & 1 & 9 & 39 & 50 & 100 \\
\hline VI & Kemudahan Penempatan Sementara & & & & & & \\
\hline 1 & $\begin{array}{l}\text { Pihak pemaju menanggung semua kos } \\
\text { pemindahan sementara termasuk sewa bulanan } \\
\text { rumah sementara tersebut }\end{array}$ & 0 & 0 & 4 & 39 & 57 & 100 \\
\hline
\end{tabular}




\begin{tabular}{|c|c|c|c|c|c|c|c|}
\hline 2 & $\begin{array}{l}\text { Rumah sementara yang disediakan adalah jauh } \\
\text { daripada rumah lama }\end{array}$ & 27 & 13 & 7 & 39 & 14 & 100 \\
\hline 3 & $\begin{array}{l}\text { Rumah sementara lebih selesa daripada rumah } \\
\text { yang lama }\end{array}$ & 3 & 1 & 9 & 50 & 37 & 100 \\
\hline
\end{tabular}

Di samping itu juga, rata-rata responden sangat bersetuju (56\%) dan bersetuju (39\%) bahawa kualiti bekalan air, elektrik dan komunikasi akan lebih baik di perumahan yang baharu dan keselamatan atau masalah vandalisme lebih terkawal selepas penduduk berpindah ke perumahan yang baharu iaitu pandangan pemilik unit sebanyak 50 peratus sangat setuju, 39 peratus bersetuju, 9 peratus tidak pasti dan 1 peratus tidak bersetuju. Ini menunjukkan bahawa faktor kemudahan asas serta keselamatan penduduk tidak boleh dipandang ringan oleh pihak berkuasa apabila melaksanakan penempatan semula penduduk.

Dalam konteks kemudahan petempatan sementara, hampir kesemua responden iaitu 57 peratus sangat bersetuju dan 39 peratus bersetuju bahawa pihak pemaju perlu menanggung semua kos pemindahan sementara termasuk sewa bulanan rumah sementara tersebut manakala 4 peratus lagi tidak pasti akan hal tersebut. Responden juga merasakan rumah sementara lebih selesa daripada rumah yang lama iaitu 50 peratus sangat bersetuju dan 37 peratus bersetuju dan 9 peratus tidak pasti. Namun, 4 peratus daripada jumlah responden pula menyatakan tidak bersetuju terhadap keselesaan rumah sementara yang disediakan. Dari segi jarak rumah sementara yang disediakan, rata-rata responden iaitu melebihi 50 peratus merasakan jarak yang jauh dari rumah lama, manakala selebihnya 7 peratus tidak pasti dan 40 peratus merasakan jarak tidak begitu jauh. Oleh itu, dapat dirumuskan bahawa pihak berkuasa perlu menyediakan kemudahan rumah sementara yang selesa kepada penduduk dengan jarak yang tidak jauh daripada rumah asal serta penduduk tidak mahu menanggung sebarang kos baik dari segi pemindahan keluar masuk rumah sehingga sewa bulanan di rumah sementara tersebut. Namun begitu, berdasarkan kepada pemerhatian pengkaji, rancangan pemindahan sementara tidak keseluruhan pemilik tetapi hanya sebahagian penduduk yang terlibat berdasarkan pelan pembangunan yang diluluskan oleh pihak berkuasa tempatan. Hal ini sedikit sebanyak dapat mengurangkan isu bantahan daripada pihak penduduk terhadap program penempatan semula.

Jadual 5: Pandangan Penduduk dalam Aspek Sosioekonomi

\begin{tabular}{lc}
\hline \multicolumn{1}{c}{ Kenyataan } & Min \\
\hline $\begin{array}{l}\text { Penduduk akan mendapat rumah baharu yang lebih luas dan } \\
\text { selesa }\end{array}$ & 4.5286 \\
$\begin{array}{l}\text { Nilainya pasaran rumah baharu lebih tinggi berbanding } \\
\text { rumah yang lama }\end{array}$ & 4.1714 \\
$\begin{array}{l}\text { Penduduk perlu membayar sejumlah wang untuk } \\
\text { mendapatkan rumah gantian yang baharu }\end{array}$ & 3.0429 \\
$\begin{array}{l}\text { Banyak peluang ekonomi yang tersedia untuk direbut oleh } \\
\text { penduduk seperti berniaga kecil-kecilan } \\
\text { Kos sara hidup meningkat selepas pembangunan semula siap } \\
\text { dilaksanakan }\end{array}$ & 4.1429 \\
$\begin{array}{l}\text { Perniagaan kecil-kecilan yang ada di sekitar perumahan } \\
\text { awam pada masa ini tidak akan diteruskan lagi }\end{array}$ & 3.8857 \\
$\begin{array}{l}\text { Pekerjaan semasa saya tidak terjejas jika berpindah ke } \\
\text { perumahan yang baharu. }\end{array}$ & 3.2143 \\
Banyak peluang pekerjaan tersedia kepada penduduk \\
$\begin{array}{l}\text { setempat } \\
\text { Sebahagian penduduk perlu mencari pekerjaan lain kerana } \\
\text { lokasi perumahan yang baharu jauh daripada tempat kerja } \\
\text { yang lama } \\
\text { Jarak untuk menggunakan perkhidmatan pengangkutan awam } \\
\text { seperti LRT/ERL dan lain-lain lebih dekat berbanding } \\
\text { sekarang }\end{array}$ & 4.0000 \\
\hline
\end{tabular}




\begin{tabular}{ll}
\hline $\begin{array}{l}\text { Penduduk akan mendapat perkhidmatan kesihatan dan } \\
\text { pendidikan yang lebih baik selepas pembangunan semula. }\end{array}$ & 4.3286 \\
$\begin{array}{l}\text { Penduduk sudah selesa dengan tahap kemudahan awam yang } \\
\text { ada sekarang dan tidak perlu dinaiktarafkan lagi }\end{array}$ & 3.7143 \\
$\begin{array}{l}\text { Penduduk akan menikmati kemudahan dan fasiliti yang lebih } \\
\text { baik di perumahan yang baharu }\end{array}$ & 4.4143 \\
$\begin{array}{l}\text { Kualiti bekalan air, elektrik dan komunikasi akan lebih baik } \\
\text { di perumahan yang baharu }\end{array}$ & 4.4857 \\
$\begin{array}{l}\text { Keselamatan atau masalah vandalisme lebih terkawal selepas } \\
\text { penduduk berpindah ke perumahan yang baharu }\end{array}$ & 4.3429 \\
$\begin{array}{l}\text { Pihak pemaju menanggung semua kos pemindahan sementara } \\
\text { termasuk sewa bulanan rumah sementara tersebut }\end{array}$ & 4.5286 \\
$\begin{array}{l}\text { Rumah sementara yang disediakan adalah jauh daripada } \\
\text { rumah lama }\end{array}$ & 3.0000 \\
Rumah sementara lebih selesa daripada rumah yang lama & 4.1714 \\
\hline
\end{tabular}

Merujuk kepada Jadual 4.8 di atas, 18 sebab bantahan penduduk dalam aspek sosioekonomi mendapati bahawa hampir kesemua sebab mempunyai nilai purata min yang dominan iaitu min melebihi 4.000 $(M>4.000)$. Dalam konteks ini, pihak yang perlu menyediakan rumah baharu yang lebih luas dan selesa dan selain perlu menanggung semua kos pemindahan sementara termasuk sewa bulanan rumah telah mendapat nilai min tertinggi dan paling dominan iaitu $M=4.5286$ diikuti oleh kualiti bekalan air, elektrik dan komunikasi akan lebih baik di perumahan yang baharu iaitu $M=4.4857, S D=0.6537$. Manakala nilai min yang terendah adalah rumah sementara yang disediakan adalah jauh daripada rumah lama iaitu $M=3.000, S D=1.4842$. Secara umumnya, sebab yang paling signifikan penduduk membantah dengan penempatan semula adalah kegagalan pihak berkuasa dalam memberikan rumah gantian yang selesa dan luas daripada rumah asal. Selain itu, jika terdapat kos yang perlu ditanggung oleh penduduk dalam urusan pemindahan ke rumah sementara atau ke rumah baharu, penduduk sama sekali tidak akan bersetuju dengan pemindahan tersebut. Sebab-sebab lain pula yang perlu diambil berat oleh pihak berkuasa adalah seperti jarak rumah sementara yang jauh daripada rumah asal, faktor keselamatan yang diabaikan, kemudahan asas yang tidak berkualiti, akses kepada pengangkutan awam yang lemah telah menunjukkan dapatan yang signifikan berdasarkan nilai purata yang melebihi 4.000 $(M>4.0000)$.

\section{Pandangan Pendudukdalam aspeksosiopolitik dan undang-undang}

Berdasarkan Jadual 6, dari segi rundingan dan keterlibatan penduduk, majoriti responden bersetuju bahawa pihak kerajaan atau pemaju telah memberikan penerangan tentang projek pembangunan semula secukupnya iaitu pemilik unit yang sangat bersetuju sebanyak 46 peratus, bersetuju 40 peratus dan tidak pasti sebanyak 10 peratus. Manakala yang tidak bersetuju sebanyak 4 peratus. Dari segi peluang yang diberikan kepada penduduk untuk memberikan pandangan dan pendapat semasa proses perancangan pembangunan semula diadakan, rata-rata 51 peratus pemilik unit bersetuju dan 40 peratus sangat bersetuju, sejumlah 7 peratus tidak pasti dan 2 peratus tidak bersetuju dengan rundingan yang diadakan. Selain itu, majoriti penduduk juga merasakan hubungan di antara penduduk dengan pihak kerajaan atau pemaju sangat rapat disebabkan projek pembangunan semula ini. Hal ini dibuktikan apabila 50 peratus pemilik unit bersetuju dan 27 peratus sangat bersetuju dengan kenyataan tersebut. Namun, terdapat sebilangan 17 peratus daripada pemilik unit tidak pasti dan selebihnya 2 peratus daripada jumlah responden tidak bersetuju akan hubungan tersebut. Berdasarkan perangkaan ini, dapat dirumuskan bahawa antara sebab penduduk membantah dengan penempatan semula adalah apabila penduduk tidak diberikan taklimat atau penerangan yang jelas tentang perancangan pihak berkuasa terhadap urusan penempatan semula penduduk. Selain itu tindakan bantahan juga didorong apabila tahap keterlibatan penduduk yang sangat rendah terutama dalam memberi peluang mengemukakan pendapat atau cadangan berkenaan urusan penempatan semula. Kewujudan jurang hubungan antara penduduk dan pihak berkuasa juga menjadi sebab penduduk mengambil tindakan membantah penempatan semula. 
Dalam konteks jaminan hak milik rumah, kebanyakan responden bersetuju (51\%) dan sangat bersetuju (37\%) bahawa penduduk bimbang tidak mendapat hak ke atas rumah yang baharu sepertimana hak milik rumah yang lama, manakala masing-masing 9 peratus tidak pasti dan 3 peratus daripada responden yang tidak setuju mengenai hal tersebut. Di samping itu, majoriti penduduk juga masih kabur tentang proses yang akan berlaku bagi urusan hak milik rumah baharu. Namun, pada masa yang sama penduduk yakin dengan jaminan yang diberikan oleh pihak berkuasa tentang hak sebagai pemilik rumah baharu iaitu 55 peratus bersetuju, 34 peratus sangat bersetuju dan 10 peratus lagi tidak pasti akan hal tersebut. Tambahan pula, dari segi undang-undang pemilikan harta pula, majoriti $59 \%$ bersetuju dan 35\% sangat bersetuju) daripada jumlah responden dan penduduk sedar kewujudan undang-undang pemilikan harta yang tidak boleh disangkal oleh mana-mana pihak dan majoriti penduduk juga akan menggunakan haknya untuk membantah selagi tuntutan yang dikemukakan tidak dipersetujui oleh pihak berkuasa. Berdasarkan kepada perangkaan ini, jelas menunjukkan bahawa sekiranya pihak berkuasa gagal memberikan hak milik yang sah kepada pemilik seperti mana hak milik yang diterima untuk rumah asal, maka penduduk membantah dengan penempatan semula ini. Walaupun penduduk yakin dengan jaminan yang diberikan oleh pihak berkuasa tentang pengekalan hak pemilikan tersebut, namun mereka masih ragu selagi tiada dokumen rasmi yang dimeterai di antara penduduk dengan pihak berkuasa. Hal ini disokong dengan dapatan berkaitan dengan tahap kesedaran yang tinggi penduduk terhadap undang-undang yang melindungi hak mereka. Majoriti penduduk faham bahawa mereka dilindungi oleh undang-undang berkenaan Hal Pemilikan Harta yang terus mendorong penduduk untuk mengambil tindakan perlu selagi mereka merasakan bahawa hak mereka tidak dipenuhi oleh pihak berkuasa.

Jadual 6: Pandangan penduduk dalam aspek sosiopolitik dan undang-undang

\begin{tabular}{|c|c|c|c|c|c|c|c|}
\hline \multirow{2}{*}{ Bil } & \multirow{2}{*}{ Kenyataan } & \multicolumn{5}{|c|}{ Skala } & \multirow{2}{*}{ Jumlah } \\
\hline & & 1 & 2 & 3 & 4 & 5 & \\
\hline
\end{tabular}

\section{Rundingan dan Keterlibatan Penduduk}

1 Pihak kerajaan/pemaju telah memberikan secukupnya

Hubungan di antara penduduk dengan pihak

2 kerajaan/pemaju sangat rapat disebabkan projek pembangunan semula ini

Penduduk diberikan peluang untuk memberikan

3 pandangan dan pendapat semasa proses perancangan pembangunan semula diadakan

\section{Jaminan Hak Milik Rumah}

Penduduk bimbang tidak mendapat hak ke atas

1 rumah yang baharu sepertimana hak milik rumah yang lama

2 Penduduk masih kabur tentang proses yang akan berlaku bagi urusan hak milik rumah baharu.

$\begin{array}{lllll}0 & 4 & 10 & 40 & 46\end{array}$

1

4

$17 \quad 50$

Penduduk yakin dengan jaminan yang diberikan

3 oleh pihak berkuasa tentang hak sebagai pemilik rumah baharu

$\begin{array}{cccccc}0 & 3 & 9 & 51 & 37 & 100 \\ 3 & 3 & 26 & 35 & 33 & 100 \\ 1 & 0 & 10 & 55 & 34 & 100\end{array}$

\section{Undang-undang Hak terhadap Harta}

Penduduk sedar kewujudan undang-undang

1 pemilikan harta yang tidak boleh disangkal oleh mana-mana pihak

$\begin{array}{llllll}0 & 0 & 6 & 59 & 35 & 100\end{array}$




\begin{tabular}{|c|c|c|c|c|c|c|c|}
\hline 2 & $\begin{array}{l}\text { Penduduk akan menggunakan haknya untuk } \\
\text { membantah selagi tuntutan yang dikemukakan } \\
\text { tidak dipersetujui oleh pihak berkuasa }\end{array}$ & 0 & 0 & 6 & 41 & 53 & 100 \\
\hline & $\begin{array}{l}\text { Penduduk terpaksa akur sekiranya Akta } \\
\text { Pengambilan Tanah diguna pakai oleh kerajaan } \\
\text { untuk memindahkan penduduk ke tempat yang } \\
\text { lain }\end{array}$ & 3 & 19 & 14 & 44 & 20 & 100 \\
\hline
\end{tabular}

Walaupun, majoriti penduduk akur dengan pemakaian Akta Pengambilan Tanah oleh kerajaan sebagai langkah akhir untuk merealisasikan penempatan semula penduduk, namun akta tersebut bukan alasan untuk penduduk berputus asa dalam mendapatkan hak yang sewajarnya. Berdasarkan pemerhatian pengkaji, penduduk masih boleh mengemukakan bantahan kepada mahkamah sekiranya pampasan yang diperoleh tidak memadai dengan kerugian yang penduduk alami. Dalam hal ini dapat dirumuskan bahawa sebab penduduk membantah dengan penempatan semula adalah kerana mereka sedar bahawa mereka dilindungi oleh undang-undang dalam hak pemilikan harta dan terus membantah sekiranya terdapat sebarang ketidakpuasan hati yang berlaku.

Jadual 7: Pandangan Penduduk dalam aspek sosiopolitik dan undang-undang

\begin{tabular}{lc}
\hline \multicolumn{1}{c}{ Kenyataan } & Min \\
\hline $\begin{array}{l}\text { Pihak kerajaan/pemaju telah memberikan penerangan tentang } \\
\text { projek pembangunan semula secukupnya }\end{array}$ & 4.2714 \\
$\begin{array}{l}\text { Hubungan di antara penduduk dengan pihak kerajaan/pemaju } \\
\text { sangat rapat disebabkan projek pembangunan semula ini }\end{array}$ & 3.9714 \\
$\begin{array}{l}\text { Penduduk diberikan peluang untuk memberikan pandangan } \\
\text { dan pendapat semasa proses perancangan pembangunan }\end{array}$ & 4.2429 \\
semula diadakan & \\
$\begin{array}{l}\text { Penduduk bimbang tidak mendapat hak ke atas rumah yang } \\
\text { baharu sepertimana hak milik rumah yang lama }\end{array}$ & 4.2286 \\
$\begin{array}{l}\text { Penduduk masih kabur tentang proses yang akan berlaku bagi } \\
\text { urusan hak milik rumah baharu. }\end{array}$ & 3.9286 \\
$\begin{array}{l}\text { Penduduk yakin dengan jaminan yang diberikan oleh pihak } \\
\text { berkuasa tentang hak sebagai pemilik rumah baharu }\end{array}$ & 4.2000 \\
$\begin{array}{l}\text { Penduduk sedar kewujudan undang-undang pemilikan harta } \\
\text { yang tidak boleh disangkal oleh mana-mana pihak }\end{array}$ & 4.3000 \\
$\begin{array}{l}\text { Penduduk akan menggunakan haknya untuk membantah } \\
\text { selagi tuntutan yang dikemukakan tidak dipersetujui oleh } \\
\text { pihak berkuasa }\end{array}$ & 4.4714 \\
$\begin{array}{l}\text { Penduduk terpaksa akur sekiranya Akta Pengambilan Tanah } \\
\text { diguna pakai oleh kerajaan untuk memindahkan penduduk ke } \\
\text { tempat yang lain }\end{array}$ & 3.6000 \\
\hline
\end{tabular}

Berdasarkan kepada Jadual 7, jelas menunjukkan pandangan penduduk yang boleh menjadi kepada punca atau sebab-sebab mengapa penduduk membantah dengan program penempatan semula terutama dalam aspek sosio politik dan undang-undang adalah signifikan kerana semua pandangan tersebut mempunyai nilai purata yang melebihi $4.000(M>4.0000)$. Penduduk menggunakan haknya untuk membantah selagi tuntutan yang dikemukakan tidak dipersetujui oleh pihak berkuasa mendapat min tertinggi dan nilai purata paling dominan iaitu $M=4.4714, S D=0.6072$ diikuti oleh penduduk sedar kewujudan undang-undang pemilikan harta yang tidak boleh disangkal oleh mana-mana pihak iaitu $M$ $=4.3000, S D=0.5736$. Manakala min yang terendah adalah pilihan untuk penduduk terpaksa akur sekiranya Akta Pengambilan Tanah diguna pakai oleh kerajaan untuk memindahkan penduduk ke tempat yang lain iaitu $M=3.6000, S D=1.0954$. Kenyataan lain pula menunjukkan bahawa rata-rata ia mempengaruhi penduduk dalam aspek sosioekonomi berdasarkan nilai purata yang melebihi 4.000 $(M>4.0000)$. Berdasarkan kepada perangkaan ini, jelas menerangkan bahawa penduduk membantah penempatan semula kerana mereka sedar bahawa mereka dilindungi oleh undang-undang berkenaan dengan pemilikan harta yang telah mendorong mereka untuk terus menyuarakan pendapat atau 
bantahan sekiranya terdapat hak mereka yang disangkal oleh mana-mana pihak. Selain itu, penduduk juga menggunakan hak mereka untuk dilibatkan secara aktif dalam perancangan penempatan semula supaya impak negatif selepas pemindahan berlaku dapat diminimumkan.

Dalam pada itu juga, ketiga-tiga aspek utama iaitu sosio budaya, sosio ekonomi dan sosio politik dan undang-undang mempunyai hubung kait antara satu sama lain dengan tahap hubungan yang signifikan. Ini bermakna pihak berkuasa perlu mengambil kira semua pandangan penduduk di dalam ketiga-tiga aspek dengan memasukkannya dalam perancangan pembangunan dan penggubalan polisi terutama berkaitan dengan penempatan semula tanpa mengabaikan mana-mana aspek kerana ianya boleh menjadi punca kepada bantahan penduduk. Perkara ini selaras dengan dapatan Jim (2003) yang juga secara empirikalnya telah membuktikan bahawa nilai budaya masyarakat mempunyai hubungan yang positif dengan pembangunan sosio ekonomi di sesebuah kawasan. Hal ini disokong oleh Jan V.D (2005) yang menyatakan bahawa hubungan budaya dengan sesebuah komuniti yang menitik beratkan hal keselamatan dan hubungan harmoni merupakan faktor strategik dalam memacu pembangunan ekonomi dan kemajuan fizikal.

\section{Kesimpulan}

Secara kesimpulannya, dapatan penduduk berhubung dengan bantahan mereka terhadap pelaksanaan projek pembangunan semula di tapak perumahan awam di Bandar Tun Razak, Kuala Lumpur. Terdapat tiga faktor yang mendorong tindakan mereka terhadap bantahan antaranya ialah sosio ekonomi, sosio budaya dan sosio politik dan undang-undang. Tiga faktor ini perlu diambil berat oleh pihak berkuasa dalam memastikan proses penempatan semula berjalan dengan lancar bagi memberi laluan kepada projek pembangunan semula di kawasan perumahan tersebut. Semua aspek yang dikenal pasti ini penting untuk dijadikan sebagai rujukan atau panduan kepada pihak berkuasa dalam memahami keperluan dan kehendak penduduk sebelum penduduk yakin untuk menyatakan persetujuan ditempatkan semula ke kawasan atau unit rumah yang baharu.

\section{Rujukan}

Ahmed Shareef Nafees. (2005). An exploration of resettlement and its impact on social services: the case of the Maldives. School of Development Studies of the University of East Anglia

Abebe G., \& Jan Hesselberg, (2013). Implications of Urban Development-Induced Resettlement on Poor Households in Addis Ababa. Ghana Journal of Geography, 5, 13- 32.

Courtland, R. (2003). Risks and Rights: the Causes, Consequences, and Challenges of DevelopmentInduced Displacement, The Brookings Institutions -SAIS Project on Internal Displacement, May 2003

Anthony, O. S. (1991). Involuntary resettlement, resistance and political empowerment, Department of Anthropology, University of Florida, USA. Journal of Refugee Studies, 4(2), 34-44.

Cernea, M. M. (1988a). Involuntary resettlement in development projects, Washington DC,The World Bank, (1988b) Non-governmental organizations and local development, Washington DC, The World Bank.

Cernea, M. M. (2000). Risks, safeguards and reconstruction: A model for population displacement and resettlement in M.M. Cernea and C. McDowell (eds.) Risks and reconstruction: Experiences of resettlers and refugees pp. 11-55. Washington DC: The World Bank.

Downing, T. (2002). Avoiding new poverty: mining induced displacement and resettlement, Report on Mining, Minerals and Sustainable Development. International Institute for Environment and Development. MMSD Project.

Eftimie, A., Heller, K., \& Strongman, J. (2009). Mainstreaming gender into extractive industries projects: guidance note for task team leaders. Washington (DC): World Bank; http://siteresources.worldbank.org/EXTOGMC/Resources/eifd9_gender_guidance.pdf

Fariz Rusadio. (2015). Bantah pembangunan semula Flat Seri Labuan, artikel Utusan Online, 18 September 2015. 
Frank, V. (2016). Project-Induced Displacement And Resettlement: From Impoverishment Risks To An Opportunity For Development?, Faculty Of Spatial Sciences, Department Of Cultural Geography, University Of Groningen, 3-21.

Hanna, P., Vanclay, F., Langdon, E. J, \& Arts, J. (2016). Conceptualizing social protest and the significance of protest actions to large projects. The Extractive Industries and Society, 3, 217-239.

Jabatan Perancang Bandar dan Desa Semenanjung Malaysia (2012). Garis panduan perancangan: pengenalpastian bagi pembangunan semula kawasan brownfield. Kementerian Perumahan dan Kerajaan Tempatan.

Jan Van, D. B, \& Antonio, P. R. (2005). The impacts of culture on the economic development of cities. European Institute for Comparative Urban Research Erasmus University Rotterdam.

Jim, G., Ronald, I., David, L. (2003). The effects of Culture Values on Economic Development: Theory, Hypothesis and some Empirical Tests. American Jurnal of Political Science, 40(3), 60-631.

Laporan Tahunan Perbadanan Pembangunan Bandar (UDA). (1984). Jilid 9.

Marris, P. (1986). Loss and change, (revised ed.), London, Routledge \& Kegan Paul.

Prabhat, B., Sibsankar, M., Sandip, T., Sumanta Mandal \& Bikash, G. (2013). Development-Induced Displacement And Human Development Through Industrialisation In India, Department of Geography, S.S.M. College, Keshpur, Paschim Medinipur, West Bengal, India African Journal of Geo-Science Research, 1(3), 10-21.

Reddy, G., Smyth, E., \& Steyn, M. (2015). Land access and resettlement: A guide to best practice. Sheffield: Greenleaf.

Sejal Patel, Richard Sliuzas, and Navdeep Mathur. (2015). The Risk of Impoverishment in Urban Development-Induced Displacement And Resettlement In Ahmedabad. Environment and Urbanization, 27(1), 231-256.

Selvi Narayanan \& Katiman Rostam. (2012). Impak Sosial Pembangunan Bandar Baru Putrajaya Terhadap Penduduk Asal: Kes Isi Rumah Yang Dipindahkan Ke Taman Permata, Dengkil, Selangor. Geografia Online: Malaysia Journal of Society and Space 8(4), 75-87.

Sharifah Mariam Alhabshi. (2012). Kampung Dalam Bandar; Cabaran Pembangunan Semula. Akademika, 82(2), 69-80.

Vanclay, F., \& Smyth, E. (2017). The social framework for projects: a conceptual but practical model to assist in assessing, planning and managing the social impacts of big projects. Impact Assess Project Appraisal, 35, 65-80.

Vincent, R., Luciano, B., Karen, S., \& Jelena, L. U. (2017). Land Acquisition and Involuntary Resettlement, Linking Innovation and Local Benefits, The World Bank Group.

Wisko anak Angin. (2009). Persepsi Penduduk Terhadap Saranan Penempatan Semula, Kajian Kes; Kawasan Penempatan Empangan Bengoh, Kuching Sarawak. Sekolah Sains Sosial, Universiti Malaysia Sabah. 